\title{
Evaluation of The Relationship between the Mastoid Process and Some Anthropometric Points on the Skull with Computed Tomography
}

\section{Processus Mastoideus ile Kafatasında Bulunan Bazı Antropometrik Noktalar Arasındaki İlişkinin Bilgisayarlı Tomografi ile Değerlendirilmesi}

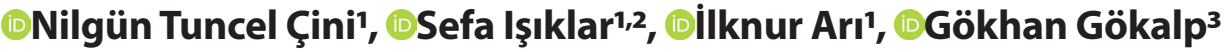 \\ 1 Bursa Uludağ University, School of Medicine, Department of Anatomy, Bursa, Turkey \\ 2 Bursa Uludağ University, Vocational School of Health Service, Medical Imaging Techniques Program, Bursa, Turkey \\ ${ }^{3}$ Bursa Uludağ University, School of Medicine, Department of Radiology, Bursa, Turkey
}

\begin{abstract}
Aim: Facial reconstruction is a method that estimates the face shape of the unidentified person using clay and similar material in cases where only the skull is present. Due to natural events and animals, the integrity of the skeletal remains can be disrupted and this makes identification hard. The aim of the study is to estimate the skull shape by reference to the mastoid process in case of fragmentation of the skull at the scene.

Material and Methods: In the study, computerized tomography images of a total of 96 adult individuals of 51 females and 45 males which were obtained from Bursa Uludag University Faculty of Medicine, Department of Radiology, were used. The variables determined in the images taken in the Frankfurt Horizontal plan were measured using the Image J program. Statistics of the data obtained were carried out using SPSS 22.0 program.

Results: The descriptive values of the variables were given. While it was seen that linear distances differed between males and females, it was seen that angular variables did not show a gender difference. Regression formulas were developed to predict missing parts and the formulas which have the highest accurate percentage is for males; $\mathrm{M} 5=-2.945+(0.548 \times \mathrm{M} 4)$ $+(0.404 \times M 6)$ and for females M5 $=-7.457+(0.409 \times M 4)+(0.619 \times M 6)$

Conclusion: In this study, we tried to evaluate the facial reconstruction from a different point of view. We have developed regression formulas with high reliability, taking into account the correlation coefficients between deciduous variables. We believe that all this data will benefit especially forensic anthropologists. In addition, we think that the fact that the angular values did not show a gender difference can be accepted as an indicator from a different perspective that the face develops at a certain rate of development.
\end{abstract}

Keywords: Skull, regression, temporal bone, mastoid process, facial reconstruction

\section{Öz}

Amaç: Yeniden yüzlendirme, yalnızca kafatasının var olduğu durumlarda kil ve benzeri materyal ile kimliklendirilmesi yapılamayan kişinin yüz şeklinin tahmin edildiği bir yöntemdir. Doğa olayları ve hayvanlar nedeniyle iskelet kalıntılarının bütünlüğü bozulabilmektedir bu da kimliklendirmeyi zor hale getirmektedir. Çalışmanın amacı, kafatasının olay yerinde fragmente olması durumunda, processus mastoideus referans alınarak kafatası şeklinin tahmin edilmesidir.

Gereç ve Yöntem: Çalışma, Bursa Uludağ Üniversitesi Tıp Fakültesi Radyoloji Anabilim Dalı'ndan elde edilen erişkin 51 kadın ve 45 erkek olmak üzere toplam erişkin 96 bireyin bilgisayarlı tomografi görüntüleri kullanıldı. Frankfurt Horizontal planında alınan görüntülerde belirlenen değişkenler Image J programı kullanılarak ölçüldü. Elde edilen verilerin istatistikleri SPSS 22.0 programı kullanılarak gerçekleştirildi.

Bulgular: Değişkenlerin betimleyici değerleri verildi. Lineer mesafelerin kadın ve erkeklerde fark gösterdiği görülürken açısal değişkenlerin cinsiyet fark göstermediği görüldü. Eksik parçaları tahmin etmek için regresyon formülleri geliştirildi ve en yüksek doğruluk yüzdesine sahip formüller erkekler için; M5= $-2,945+(0,548 \times M 4)+(0,404 \times M 6) ;$ kadınlar için M5 $=-7,457+(0,409 \times M 4)+$ $(0,619 \times M 6)$ olarak bulunmuştur.

Sonuç: Çalışmada yeniden yüzlendirmeyi farklı bir bakış açısıyla değerlendirmeye çalıştık. Değişkenler arasındaki korelasyon katsayılarını dikkate alarak yüksek güvenilirliğe sahip regresyon formülleri geliştirdik. Tüm bu verilerin özellikle adli antropologlara fayda sağlayacağına inanıyoruz. Ayrıca açısal değerlerin cinsiyet farkı göstermemiş olması yüzün belirli bir oranda gelişim gösterdiğinin farklı bir açıdan göstergesi olarak kabul edilebilir olabileceğini düşünmekteyiz.

Anahtar Kelimeler: Kafatası, regresyon, temporal kemik, processus mastoideus, yeniden yüzlendirme

Corresponding (illetişim): Nilgün TUNCEL ÇiNi, Dr. PhD, Bursa Uludag University School of Medicine Department of Anatomy, Bursa, Turkey E-mail (E-posta): nntuncel@gmail.com 


\section{INTRODUCTION}

Identification is one of the priority subjects of the forensic sciences. Age, gender, ethnicity and height form the biological profile of the individual and they are the basis of the identification. ${ }^{[1]}$ There are so many methods to assess the identification of the person but DNA analysis is the most reliable among these. The only disadvantage is that after a long time and if the corpse is fully skeletonized, the appropriate quality and quantity of the DNA cannot be reached at the crime scene. In this case, skeletal forensic identification is preferred as the last method. ${ }^{[2]}$ Because the skeletal elements are affected by taphonomic factors in a longer time, it usually takes longer times for them to disappear completely. ${ }^{[2,3]}$ One of the methods that used to identify skeletal remains of unknown origin or to obtain information about the identity of the corpses in cases where there is little or no evidence at the crime scene is facial reconstruction. In this method, it is estimated that only the skull exists at the scene, and in cases where soft tissue cannot be obtained, the shape of the person's face. Depending on the tissue thickness at various anatomical points on the face, tissue depth markers such as vinyl or rubber are used in different lengths. Then, organs such as lips, cheeks, eyes and nose are placed. ${ }^{[4]}$

In facial reconstruction, the position of the soft tissue relative to the underlying bone structure and the consistency of the anatomical connection between it is an important issue. To assess this consistency, a comprehensive understanding of the anatomy of the skull and the relationship between the skull and the face is thoroughly required. ${ }^{[2]}$ It causes deterioration of the integrity of skeletal remains due to natural events such as climate, wind and surrounding animals. For this reason, working with fragmented bones with impaired integrity makes identification hard..$^{[5]}$ In human skull sex determination, the petrous part of the temporal bone has a special importance among the bones used as the base due to its compact structure that can withstand mechanical effects and other destructive factors such as temperature. ${ }^{[6]}$ By using the morphological features of bones, mathematical models can be made by means of morphometric methods, and an individual's age, height and gender can be estimated. Studies indicate that bones differ according to gender and ethnicity, so regression formulas for each population should be produced. ${ }^{[7,8]}$

The aim of the study is to give descriptive values for the estimation of the skull shape and to produce regression formulas, by taking the mastoid process as reference in case of fragmented or missing parts of the skull at the scene.

\section{MATERIAL AND METHOD}

The study was conducted as a result of the decision of the Bursa Uludağ University Faculty of Medicine Clinical Research Ethics Committee dated 20 July 2020 and numbered 2020-12/23. Cranial, face and neck computed tomography (CT) images taken using Siemens Somatom Definition 128-section multi-detector computed tomography device in the xxx University Faculty of
Medicine, Department of Radiology are used. Images, protocol numbers, and three-dimensional computed tomography images obtained with Centricity RIS 6.0 Plus PACS system (General Electric Company, USA) were brought to jpeg format on Workstation. After selecting the $1.5 \mathrm{~mm}$ thick thin-section axial images in the GFPACS system, reformat images were created with the AW Suite 2.0 program and evaluated in the bone window. Sagittal and coronal images of skulls rendered in $3 \mathrm{D}$ with the volume are rendering option on the program. It was brought to the Frankfurt Horizontal Plan separately and recorded in the PACS system via AW Suite 2.0. Afterwards, images of adult females and males individuals were filed separately in jpeg format and made ready for measurement.

\section{Study Group}

In the retrospective study, 1260 computed tomography images that the report files could be accessed were examined. Individuals with fractures, deformities, or any pathological findings and a history of surgery and trauma were excluded from the study. A total of 96 adult individuals, 51 females and 45 males, were included in the study. The age range for males was $19-65$, and the mean age was $36.82 \pm 14.18$ years. The age range for females was $18-66$, and the mean age was 35.76 \pm 14.18 .

\section{Measurements}

Variables were chosen by selecting anthropometric points that reveal the convexity and concavity of facial features with reference to the mastoid process. The linear distances from the mastoid process to the anthropometric points that glabella, nasion, rhinion, nasospinale, A point, prosthion, infradentale, B point, pogonion, menton and gonion and the angles formed between the linear distances were measured. [9-12] The reference points were shown in Figure 1, the linear variables included in the study were shown in Figure $\mathbf{2}$ and angular variables were shown in Figure 3. After calibrating in the ImageJ program with the help of the ruler on the images recorded as jpeg, linear distances were measured in millimeters. The measured parameters are:

M1:The linear distance between mastoid process and glabella M2: The linear distance between mastoid process and nasion

M3: The linear distance between mastoid process and rhinion

M4: The linear distance between mastoid process and nasospinale

M5: The linear distance between mastoid process and A point

M6: The linear distance between mastoid process and prosthion

M7: The linear distance between mastoid process and infradentale

M8: The linear distance between mastoid process and B point

M9: The linear distance between mastoid process and pogonion

M10: The linear distance between mastoid process and menton 
M11: The linear distance between mastoid process and gonion M12: The linear distance between mastoid process and inion M13: The linear distance between mastoid process and ophistocranion

M14: Angle between glabella, mastoid process and nasion M15: Angle between nasion, mastoid process and rhinion M16: Angle between rhinion, mastoid process and nasospinale M17: Angle between nasospinale, mastoid process and $A$ point

M18: Angle between A point, mastoid process and prosthion M19: Angle between prosthion, mastoid process and infradentale

M20: Angle between infradentale, mastoid process and B point

M21: Angle between B point, mastoid process and pogonion

M22: Angle between pogonion, mastoid process and menton M23: Angle between menton, mastoid process and gonion M24: Angle between gonion, mastoid process and inion

M25: Angle between inion, mastoid process and ophistocranion

M26: Angle between ophistocranion, mastoid process and glabella

In the first phase of the facial reconstruction stages, the missing or broken parts of the skull must be completed. The parts that are broken or missing one side are completed by

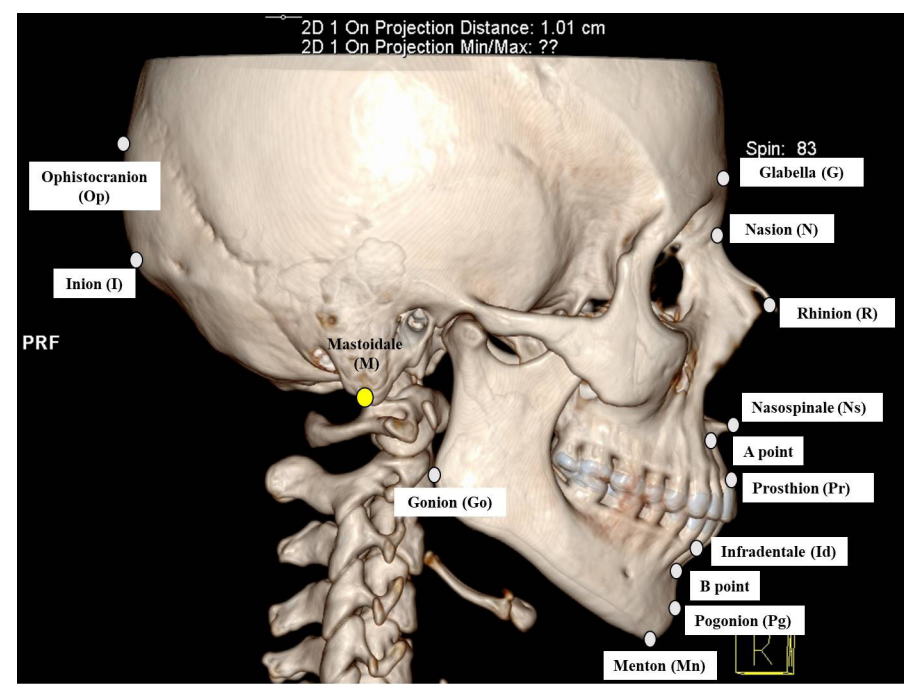

Figure 1. Anthropometric points used as reference

Mastoidale - $(\mathrm{M})$ : Lowest point of the mastoid process; Glabella -(G): The most prominent point between the superciliar arcs on the midline; Nasion-(N): Intersection point of midline and frontonasal sutur; Rhinion-(R): The junction of the nasal bone and lateral nasal cartilages on the midline; Nasospinale(Ns): anterior nasal spine crest; A point (Subspinale): Deepest point below the nasospinale; Prosthion (Supradentale)-Pr: The most anterior point of the alveolar process between the maxillary anterior incisors; Infradentale-(Id): The most anterior point of the alveolar process between the mandibular anterior incisors; B point (Supramentale): Deepest point between infradentale and pogonion; Pogonion$(\mathrm{Pg})$ :The most prominent point of the mental tubercle on the midline; Menton-(Mn): The lowest point of the mandible on the midline; Gonion-(Go): The point on the outermost edge of the angle of mandible; Inion-(I): The most prominent point of the external occipital protuberance; Ophistocranion-(Op): The most prominenet point of the occipital bone on the midline using the mirror method technique by accepting them as symmetrical with respect to the existing side. ${ }^{[13]}$ Accordingly, the lateral measurements of the variables on the right side of the skull were taken as reference.

\section{Statistical Analysis}

Descriptive statistical values in the form of mean \pm standard deviation were examined for all variables in males and females individuals. Independent sample t-test was used to reveal the difference between gender. Pearson correlation analysis was performed to determine the relationship between the variables $(p<0.05)$. Regression formulas were produced by using highly correlated variables as a result of correlation analysis. With these formulas, it was aimed to determine the shape of the face from broken or fragmented skulls. All statistical analyzes were performed using SPSS 22.0 (IBM).

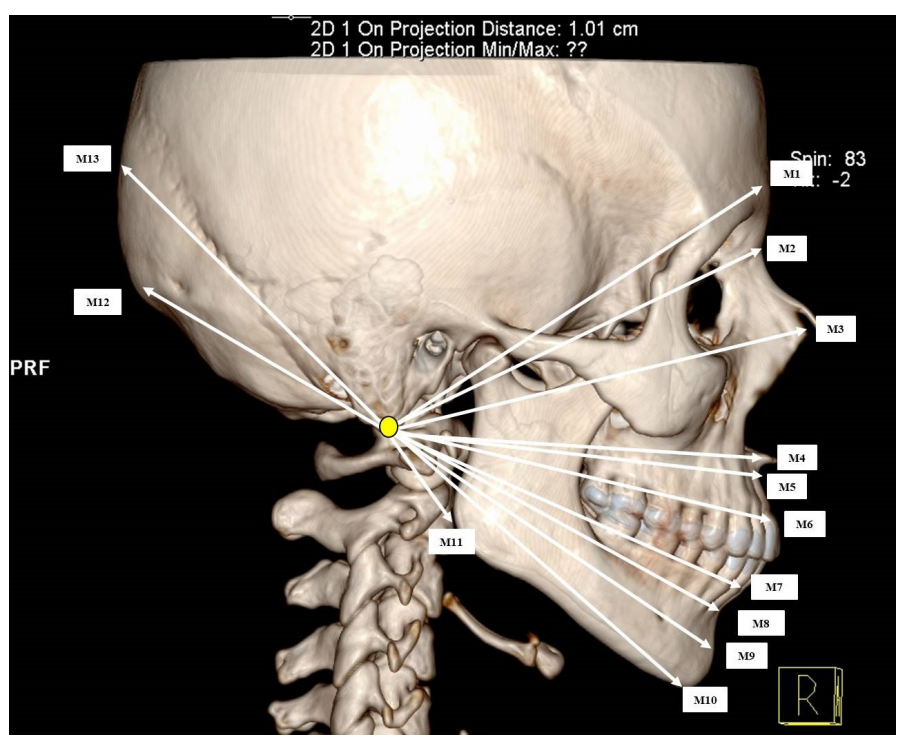

Figure 2. Parameters measured with reference to the mastoid process

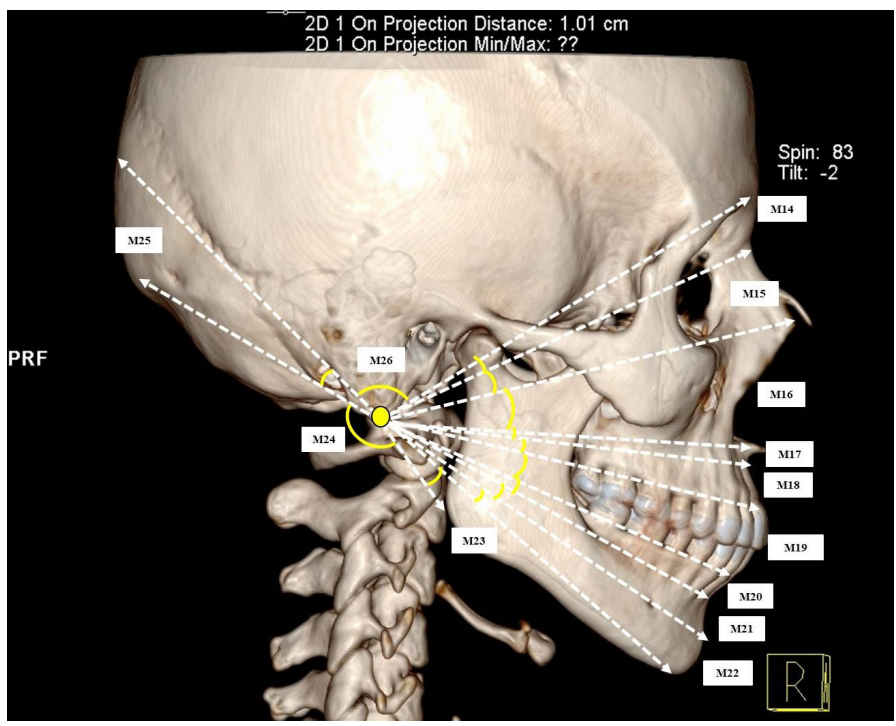

Figure 3. Angular parameters measured with reference to the mastoid process 


\section{RESULTS}

Descriptive statistical values of the variables for adult females and males individuals were examined. In males and females, the linear distances of the mastoid process to the glabella, nasion, rhinion, nasospinale, A point, prosthion, infradentale, $B$ point, pogonion, menton and gonion, and the angles formed between the distances were shown in Table 1. It was determined that the linear distances of the mastoid process to other points differ between gender while the angle between glabella-mastoid process-nasion, nasospinale-mastoid process-A point and menton-mastoid process-gonion angles showed gender difference $(p<0.05)$.

Regression analysis based on the estimation of the face shape due to fractured or fragmented skull sections was performed using variables with high correlation between the variables, separately for males and females. While performing the regression analysis, formulas are created by testing more than one variable and its combinations. It has been tried to take into account the possibility that any part of the skull is absent or missing. The adjusted $\mathrm{R} 2$ value shows us the prediction rate of the formula as a percentage. It has been achieved to produce formulas with an accuracy of $90 \%$ and above in both genders. The regression formulas produced for males were shown in Table 2, and the formulas were produced for females were shown in Table 3. The formula which has the highest accuracy percentage is for males and females respectively:
M5=-2.945+(0.548xM4)+(0.404xM6) Adjusted R2 Value: 0.945; S.E.: 1.432 M5=-7.457+(0.409xM4)+(0.619xM6) Adjusted R2 Value: 0.955; S.E.: 1.006

\begin{tabular}{lcc} 
Table 2. Regression formulas for males & & \\
Regression Formula & $\begin{array}{c}\text { Adjusted } \\
\text { R2 Value }\end{array}$ & $\begin{array}{c}\text { Standart } \\
\text { Error }\end{array}$ \\
\hline $\mathrm{M} 1=4.552+(1.047 \times \mathrm{M} 2)$ & 0.898 & 2.063 \\
$\mathrm{M} 2=7.555+(0.860 \times \mathrm{M} 1)$ & 0.898 & 1.869 \\
$\mathrm{M} 3=14.337+\left(0.459 \times \mathrm{M}^{2}\right)+(0.506 \times \mathrm{M} 4)$ & 0.907 & 1.731 \\
$\mathrm{M} 4=10.144+(0.943 \times \mathrm{M} 5)$ & 0.905 & 0.835 \\
$\mathrm{M} 4=3.886+(0.136 \times \mathrm{M} 1)+(0.836 \times \mathrm{M} 5)$ & 0.915 & 1.758 \\
$\mathrm{M} 4=-3.341-(0.028 \times \mathrm{M} 1)+(0.381 \times \mathrm{M} 3)+(0.658 \times \mathrm{M} 5)$ & 0.933 & 1.569 \\
$\mathrm{M} 4=4.077+(0.14 \times \mathrm{M} 1)+(0.901 \times \mathrm{M} 5)-(0.07 \times \mathrm{M} 6)$ & 0.914 & 1.772 \\
$\mathrm{M} 5=-0.761+(0.965 \times \mathrm{M} 4)$ & 0.908 & 1.857 \\
$\mathrm{M} 5=-11.616+(0.386 \times \mathrm{M} 3)+(0.629 \times \mathrm{M} 6)$ & 0.927 & 1.656 \\
$\mathrm{M} 5=-2.945+(0.548 \times \mathrm{M} 4)+(0.404 \times \mathrm{M} 6)$ & 0.945 & 1.432 \\
$\mathrm{M} 6=-7.174+(0.652 \times \mathrm{M} 5)+(0.439 \times \mathrm{M} 7)$ & 0.931 & 1.688 \\
$\mathrm{M} 6=-6.551+(0.766 \times \mathrm{M} 5)+(0.325 \times \mathrm{M} 8)$ & 0.903 & 1.996 \\
$\mathrm{M} 7=-0.558+(0.341 \times \mathrm{M} 6)+(0.669 \times \mathrm{M} 8)$ & 0.909 & 1.743 \\
$\mathrm{M} 7=1.344-(0.228 \times \mathrm{M} 5)+(0.551 \times \mathrm{M} 6)+(0.661 \times \mathrm{M} 8)$ & 0.914 & 1.690 \\
$\mathrm{M} 8=0.943+(0.243 \times \mathrm{M} 6)+(0.694 \times \mathrm{M} 9)$ & 0.903 & 1.652 \\
$\mathrm{M} 8=1.143+(0.457 \times \mathrm{M} 7)+(0.492 \times \mathrm{M} 9)$ & 0.929 & 1.412 \\
$\mathrm{M} 8=2.429+(0.477 \times \mathrm{M} 7)+(0.453 \times \mathrm{M} 10)$ & 0.938 & 1.326 \\
$\mathrm{M} 9=8.446+(0.908 \times \mathrm{M} 10)$ & 0.929 & 1.448 \\
$\mathrm{M} 9=6.818+(0.175 \times \mathrm{M} 7)+(0.762 \times \mathrm{M} 10)$ & 0.938 & 1.352 \\
$\mathrm{M} 10=-0.753+(1.025 \times \mathrm{M} 9)$ & 0.929 & 1.539 \\
$\mathrm{M} 10=-1.24+(0.233 \times \mathrm{M} 8)+(0.813 \times \mathrm{M} 9)$ & 0.934 & 1.489 \\
\hline & & \\
\hline
\end{tabular}

Table 1. Descriptive statistical values of distance $(\mathrm{mm})$ and angle values between mastoid process and other parameters

\begin{tabular}{|c|c|c|c|c|c|c|}
\hline \multirow{2}{*}{ Variable } & \multicolumn{3}{|c|}{ Female } & \multicolumn{3}{|c|}{ Male } \\
\hline & Mean士S.D. & Median & Min. - Max. & Mean士S.D. & Median & Min. - Max. \\
\hline M1 & $117.036 \pm 5.496$ & 117.189 & $98.393-128.908$ & $125.038 \pm 6.459$ & 125.662 & $107.916-141.596$ \\
\hline M2 & $108.573 \pm 5.339$ & 108.528 & $91.405-120.453$ & $115.047 \pm 5.852$ & 115.170 & $99.253-129.168$ \\
\hline M3 & $113.112 \pm 5.140$ & 113.720 & $98.166-123.419$ & $120.070 \pm 5.690$ & 120.288 & $105.541-133.002$ \\
\hline M4 & $100.462 \pm 4.807$ & 100.260 & $91.158-114.265$ & $104.722 \pm 6.048$ & 103.990 & $91.193-120.000$ \\
\hline M5 & $96.267 \pm 4.762$ & 96.521 & $86.358-107.619$ & $100.322 \pm 6.120$ & 99.581 & $88.752-115.302$ \\
\hline M6 & $101.141 \pm 4.587$ & 101.185 & $90.625-111.519$ & $104.172 \pm 6.418$ & 103.574 & $90.814-120.731$ \\
\hline M7 & $100.363 \pm 5.020$ & 100.933 & $89.258-109.452$ & $104.628 \pm 5.763$ & 104.017 & $94.672-118.436$ \\
\hline M8 & $99.009 \pm 5.535$ & 99.606 & $86.580-108.689$ & $104.112 \pm 5.309$ & 103.368 & $94.234-114.716$ \\
\hline M9 & $106.141 \pm 5.670$ & 106.470 & $93.025-116.678$ & $112.153 \pm 5.443$ & 111.540 & $100.253-124.290$ \\
\hline M10 & $107.726 \pm 5.977$ & 108.084 & $94.206-118.869$ & $114.227 \pm 5.784$ & 113.205 & $103.636-126.416$ \\
\hline M11 & $46.650 \pm 5.470$ & 34.197 & $46.742-56.545$ & $51.097 \pm 7.496$ & 51.235 & $35.234-77.217$ \\
\hline M12 & $70.595 \pm 10.909$ & 73.301 & $33.861-91.942$ & $79.910 \pm 8.435$ & 77.881 & $67.612-114.964$ \\
\hline M13 & $100.383 \pm 9.330$ & 99.451 & $80.716-120.946$ & $110.651 \pm 8.926$ & 112.551 & $91.467-133.061$ \\
\hline M14 & $5.258^{\circ} \pm 1.179^{\circ}$ & $5.461^{\circ}$ & $2.407^{\circ}-7.762^{\circ}$ & $4.451^{\circ} \pm 1.101^{\circ}$ & $4.218^{\circ}$ & $2.827^{\circ}-8.374^{\circ}$ \\
\hline M15 & $11.785^{\circ} \pm 1.771^{\circ}$ & $11.570^{\circ}$ & $7.086^{\circ}-17.667^{\circ}$ & $11.743^{\circ} \pm 1.963^{\circ}$ & $11.734^{\circ}$ & $8.273^{\circ}-16.189^{\circ}$ \\
\hline M16 & $15.782^{\circ} \pm 1.765^{\circ}$ & $15.844^{\circ}$ & $10.431^{\circ}-21.256^{\circ}$ & $15.488^{\circ} \pm 1.795^{\circ}$ & $15.660^{\circ}$ & $11.780^{\circ}-18.836^{\circ}$ \\
\hline M17 & $3.541^{\circ} \pm 0.846^{\circ}$ & $3.386^{\circ}$ & $1.787^{\circ}-5.678^{\circ}$ & $3.198^{\circ} \pm 0.869^{\circ}$ & $3.063^{\circ}$ & $1.728^{\circ}-5.869^{\circ}$ \\
\hline M18 & $6.432^{\circ} \pm 1.702^{\circ}$ & $6.116^{\circ}$ & $3.498^{\circ}-11.302^{\circ}$ & $6.432^{\circ} \pm 1.497^{\circ}$ & $6.582^{\circ}$ & $3.112^{\circ}-10.274^{\circ}$ \\
\hline M19 & $11.538^{\circ} \pm 1.359^{\circ}$ & $11.568^{\circ}$ & $8.491^{\circ}-14.804^{\circ}$ & $12.069^{\circ} \pm 2.080^{\circ}$ & $11.730^{\circ}$ & $8.163^{\circ}-17.361^{\circ}$ \\
\hline M20 & $5.402^{\circ} \pm 1.732^{\circ}$ & $5.343^{\circ}$ & $1.879^{\circ}-9.712^{\circ}$ & $4.844^{\circ} \pm 1.607^{\circ}$ & $4.877^{\circ}$ & $1.570^{\circ}-8.133^{\circ}$ \\
\hline M21 & $5.640^{\circ} \pm 1.499^{\circ}$ & $5.625^{\circ}$ & $1.700^{\circ}-10.238^{\circ}$ & $5.821^{\circ} \pm 1.368^{\circ}$ & $5.875^{\circ}$ & $0.818^{\circ}-8.497^{\circ}$ \\
\hline M22 & $4.794^{\circ} \pm 1.150^{\circ}$ & $4.723^{\circ}$ & $2.649^{\circ}-7.028^{\circ}$ & $4.703^{\circ} \pm 1.122^{\circ}$ & $4.779^{\circ}$ & $2.605^{\circ}-7.519^{\circ}$ \\
\hline M23 & $18.017^{\circ} \pm 3.983^{\circ}$ & $18.393^{\circ}$ & $9.982^{\circ}-26.220^{\circ}$ & $20.167^{\circ} \pm 5.025^{\circ}$ & $20.175^{\circ}$ & $8.584^{\circ}-32.724^{\circ}$ \\
\hline M24 & $144.37^{\circ} \pm 11.564^{\circ}$ & $145.954^{\circ}$ & $108.211^{\circ}-166.04^{\circ}$ & $144.984^{\circ} \pm 9.344^{\circ}$ & $146.38^{\circ}$ & $116.243^{\circ}-166.48^{\circ}$ \\
\hline M25 & $23.525^{\circ} \pm 6.695^{\circ}$ & $23.480^{\circ}$ & $8.721^{\circ}-41.897^{\circ}$ & $23.777^{\circ} \pm 5.431^{\circ}$ & $23.957^{\circ}$ & $14.201^{\circ}-34.481^{\circ}$ \\
\hline M26 & $103.942^{\circ} \pm 7.512^{\circ}$ & $105.241^{\circ}$ & $90.337^{\circ}-120.64^{\circ}$ & $102.201^{\circ} \pm 6.086^{\circ}$ & $102.58^{\circ}$ & $86.131^{\circ}-135.35^{\circ}$ \\
\hline
\end{tabular}




\begin{tabular}{|c|c|c|}
\hline Regression Formula & $\begin{array}{c}\text { Adjusted R2 } \\
\text { Vlaue }\end{array}$ & $\begin{array}{c}\text { Standart } \\
\text { Error }\end{array}$ \\
\hline $\mathrm{M} 1=10.025+(0.986 \times \mathrm{M} 2)$ & 0.927 & 1.472 \\
\hline$M 2=-5.261+(0.721 \times M 1)+(0.261 \times M 3)$ & 0.938 & 1.331 \\
\hline M5 $=-4.279+(0.994 \times M 6)$ & 0.915 & 1.386 \\
\hline $\mathrm{M} 5=-11.937+(0.227 \times \mathrm{M} 3)+(0.816 \times \mathrm{M} 6)$ & 0.945 & 1.112 \\
\hline $\mathrm{M} 5=-7.457+(0.409 \times \mathrm{M} 4)+(0.619 \times \mathrm{M} 6)$ & 0.955 & 1.006 \\
\hline $\mathrm{M} 5=-3.438+(0.752 \times \mathrm{M} 4)+(0.24 \times \mathrm{M} 7)$ & 0.903 & 1.480 \\
\hline M5 $=0.491+(0.771 \times M 4)+(0.185 \times M 8)$ & 0.891 & 1.570 \\
\hline M5 $=-3.42+(1.045 \times M 6)-(0.057 \times M 9)$ & 0.916 & 1.328 \\
\hline$M 5=-3.772+(1.028 \times M 6)-(0.037 \times M 10)$ & 0.915 & 1.391 \\
\hline$M 6=16.89+(0.15 \times M 3)+(1.051 \times M 5)$ & 0.924 & 1.262 \\
\hline$M 6=8.322+(0.768 \times M 5)+(0.188 \times M 7)$ & 0.931 & 1.205 \\
\hline$M 6=10.629+(0.789 \times M 5)+(0.147 \times M 8)$ & 0.926 & 1.245 \\
\hline $\mathrm{M} 6=8.405+(0.818 \times \mathrm{M} 5)+(0.132 \times \mathrm{M} 9)$ & 0.929 & 1.222 \\
\hline $\mathrm{M} 6=9.264+(0.831 \times \mathrm{M} 5)+(0.11 \times \mathrm{M} 10)$ & 0.926 & 1.251 \\
\hline$M 6=12.344+(0.922 \times M 5)$ & 0.915 & 1.335 \\
\hline $\mathrm{M} 7=13.852+(0.874 \times \mathrm{M} 8)$ & 0.927 & 1.357 \\
\hline$M 7=9.402+(0.13 \times M 6)+(0.786 \times M 8)$ & 0.930 & 1.325 \\
\hline $\mathrm{M} 8=-12.163+(0.133 \times \mathrm{M} 4)+(0.974 \times \mathrm{M} 7)$ & 0.933 & 1.436 \\
\hline$M 8=-8.135+(0.292 \times M 4)+(0.722 \times M 10)$ & 0.909 & 1.671 \\
\hline$M 8=-9.589+(0.345 \times M 5)+(0.711 \times M 9)$ & 0.901 & 1.745 \\
\hline $\mathrm{M} 8=-7.522+(0.338 \times \mathrm{M} 5)+(0.687 \times \mathrm{M} 10)$ & 0.916 & 1.603 \\
\hline$M 8=-9.585+(0.077 \times M 6)+(1.004 \times M 7)$ & 0.927 & 1.498 \\
\hline $\mathrm{M} 8=-9.751+(0.37 \times \mathrm{M} 6)+(0.662 \times \mathrm{M} 10)$ & 0.915 & 1.618 \\
\hline $\mathrm{M} 8=-3.181+(0.961 \times \mathrm{M} 7)+(0.123 \times \mathrm{M} 11)$ & 0.932 & 1.443 \\
\hline$M 9=7.286+(0.918 \times M 10)$ & 0.935 & 1.451 \\
\hline $\mathrm{M} 9=6.271+(0.173 \times \mathrm{M} 8)+(0.768 \times \mathrm{M} 10)$ & 0.937 & 1.423 \\
\hline $\mathrm{M} 9=11.984+(0.814 \times \mathrm{M} 10)+(0.138 \times \mathrm{M} 11)$ & 0.939 & 1.397 \\
\hline $\mathrm{M} 10=-0.518+(1.020 \times \mathrm{M} 9)$ & 0.935 & 1.529 \\
\hline
\end{tabular}

\section{DISCUSSION}

Understanding the relationship between skull and soft facial tissue is important for forensic facial reconstruction. ${ }^{[2]}$ There are so many studies about facial reconstruction, especially estimation of the facial organs like ear, nose, eye etc. for the various gender, age, and races. It is seen that these studies accept the skull as a whole without any deformity and reconstruction it in this way. Given that mass catastrophes, wars, and animal activity at the scene have disrupted the integrity of the skeletal remains, situations are likely to arise where it may be necessary to reveal the shape of the skull before attempting reconstruction The study aims to estimate the anatomical points that make up the facial contours using the mastoid process in case the skull is fractured or fragmentary.

In the literature, there are studies that tried to estimate gender using many variables such as the length of the mastoid process and its distances from the neighboring anatomical structures. ${ }^{[14,15]}$ In the study, unlike the literature, the linear distances between the mastoid process to the anthropometric points on the midline of the face and the angles between these distances were measured. When the difference between males and females individuals with comparative statistics were examined, it is seen that all linear distances showed gender differences. Among the angles, it was determined that the angle between glabella-mastoid process-nasion, the angle between nasospinale-mastoid process- $A$ point and the angle between menton-mastoid process-gonion showed gender differences, and all the other angles did not differ between males and females. It is not surprising that angular variables do not show gender differences since the rate of development of the face is constant in males and females. ${ }^{[16]}$ It made us think that some points might not have been able to adapt to this rate of development. It is seen that some angular variables differ in the study.

Considering the stability of the skull bones, the harmony between the facial bones, the maxilla, and the mandible and the effect of these bones on the vertical development of their face it is usual to find differences between males and females individuals. In male, the sharp edge of the supraorbital margin of the orbita and its extension towards the region causes the glabella to have a more prominent appearance. ${ }^{[17]}$ This explains to us the gender difference in the angle between the glabella-mastoid process-nasion.

The mandibular angle shows dimorphism due to the anteroinferior displacement of the gonion, which shortens the length of the gonial region, and the slight upward movement of the preangular notch. A longer lower margin (lower edge of the basal bone) in males and an allometric downward orientation of the preangular notch in females causes the lower margin to display a more curved appearance. These structures are also thought to be related to the enlargement of the nasopharyngeal cavity as a whole as a result of its clockwise rotation. ${ }^{[18]}$ In the study, the angle between the menton-mastoid process-gonion which shows the gender difference think that it may be due to a functional difference originating from the chewing muscles as well as being an individual. The nasal cavity shows a gender difference in males and females due to their energy requirements. ${ }^{[19]}$ We think that the shape and direction of anterior nasal spine in this region may show a gender difference because of the great differences in individuals.

In a study that use computed tomography images in the Turkish population, the distance between the mastoid process and the glabella was reported as $131.1 \pm 5.86 \mathrm{~mm}$ in males and $123.5 \pm 4.69 \mathrm{~mm}$ in females. In the same study, the distance between the mastoid process and the nasion was $121.7 \pm 5.60 \mathrm{~mm}$ in males and $115.1 \pm 4.20 \mathrm{~mm}$ in females; the distance between the mastoid process and the rhinion was $125.8 \pm 5.50 \mathrm{~mm}$ in males and $119.5 \pm 4.23$ in females. The distance between the mastoid process and the nasospinale was $110.7 \pm 5.54 \mathrm{~mm}$ in males and $106.1 \pm 3.66 \mathrm{~mm}$ in females; the distance between the mastoid process and the prosthion was specified as $109.0 \pm 5.92 \mathrm{~mm}$ in males and $105.3 \pm 3.33$ $\mathrm{mm}$ in females. ${ }^{[4]}$ When the data of our study is compared with the thesis study, it is seen that the values are lower. Apart from this study, no study using dry bone has been encountered in the literature. 
Macroscopic and radiographic measurements of dry bones or teeth are problematic due to changes in the skeleton because of taphonomic reasons. Huxley stated that postmortem shrinkage was observed in human fetal diaphyseal lengths when compared dry bones with the fresh bones. ${ }^{[20]}$ This means that indicators based on fresh bones cannot be applied directly to dry bones. ${ }^{[21]}$ The association of facial soft tissues with dry skulls is important for forensic identification or for inferring the facial morphology of extinct forms. It is known that the soft tissue of the face shows serious differences between individuals due to reasons such as embryology, growth and aging, and aesthetics. ${ }^{[22]}$ It is seen that the compatibility of the data obtained from living individuals with the dry skull or the fact that the data obtained from the cadavers do not reflect the real image, and the large differences between individuals due to environmental conditions show that facial reconstruction cannot give us a definite result.

Forensic facial reconstruction is a method for predicting possible face shape. Especially estimation of the soft tissue thickness is the main point of the studies. Before the reconstruction, restoration of the skull can be necessary and in this study, we tried to evaluate the issue from a different point of view with the mastoid process. We believe this study set an example for future studies and help the forensic sciences.

Limitations of the study: The number of the images are can be increased by dividing them into the age groups. It is recommended to examine the study with other age groups as well as the adult group and also it is possible to estimate the soft tissue with the skull.

\section{CONCLUSION}

In the case of fragmentation of the skull in the study, we tried to evaluate the skull from a different perspective in the light of the studies in the literature. In the study, we aimed to reveal the face shape on the bone by using mastoid process on the temporal bone. For this purpose, we have developed regression formulas with high reliability, taking into account the correlation coefficients between deciduous variables. We believe that all this data will benefit different disciplines, especially forensic anthropologists.

\section{ETHICAL DECLARATIONS}

Ethics Committee Approval: Ethics committee approval was obtained from Ethics Committee of Bursa Uludag University School of Medicine (Date: 20/07/2020-Decision No: 2020-12/23).

Informed Consent: Because the study was designed retrospectively, no written informed consent form was obtained from patients.

Referee Evaluation Process: Externally peer-reviewed.
Conflict of Interest Statement: The authors have no conflicts of interest to declare.

Financial Disclosure: The authors declared that this study has received no financial support.

Author Contributions: All of the authors declare that they have all participated in the design, execution, and analysis of the paper, and that they have approved the final version.

Acknowledgment: The authors thank the Department of Radiology, Bursa Uludag University for their contribution. This study is one part of the PhD thesis of the Nilgün Tuncel Çini.

\section{REFERENCES}

1. Babacan S, Kafa IM. Estimating the entire length of the fragmentary tibia with proximal and distal dimensions. Antropoloji. 2020;40:77-83.

2. Damas S, Cordón O, Ibáñez, O. Handbook on Craniofacial Superimposition. Switzerland:Springer Nature 2020;1-50.

3. Mutluay SD, Acikgoz AK, Bozkir MG. Estimation of the maximum length of the humerus from its segments' lengths. Int J Morphol 2020;38(5):1350-5.

4. Babacan S, Isiklar S, Kafa IM, Gokalp G. Redesign of missing mandible by determining age group and gender from morphometric features of skull for facial reconstruction (approximation). Archaeol Anthropol Sci. 2021;13:75.

5. Wright LE. Vásquez MA. Estimating the length of incomplete long bones:Forensic standards from Guatemala. Am J Phys. 2003;120(3):23351.

6. Kozerska M, Skrtatz J, Sczepanek A. Application of the temporal bone for sex determination from the skeletal remains. Folia Med Crac. 2015;55(2):33-9.

7. Duyar I, Pelin C. Body height estimation based on tibia length in different stature groups. Am J Phys Anthropol. 2003;122(1):23-7.

8. Radoinova D, Tenekedjiev K, Yordanov Y. Stature estimation from long bone lengths in Bulgarians. Homo. 2002;52(3):221-32.

9. Abdel Fatah EE, Shirley NR, Jantz RL, Mahfouz MR. Improving sex estimation from -crania using a novel three-dimensional quantitative method. J Forensic Sci. 2014;59(3):590-600.

10. Franchi L, Pavoni C, Cerroni S, Cozza P. Thin-plate spline analysis of mandibular morphological changes induced by early class III treatment:a long-term evaluation. Eur J Orthod. 2014;36:425-30.

11. Ibrahim A, Alias A, Nor FM, Swarhib M, Abu Bakar SN, Das S. Study of sexual dimorphism of Malaysian crania:an important step in identification of the skeletal remains. Anat Cell Biol. 2017;50:86-92.

12. Kragskov J, Bosch C, Gyldensted C, Sindet-Pedersen S. Comparison of the reliability of craniofacial anatomic landmarks based on cephalometric radiographs and three-dimensional CT scans. Cleft Palate Craniofac J. 1997;34(2):111-16.

13. Aka S, Şakul U. Kimliği bilinmeyen bir olgunun anatomik yeniden yüzlendirme tekniği ile kimliklendirilmesi. Adli Bilimler Dergisi/Turkish Journal of Forensic Sciences. 2007;6(1):65-70.

14. Çalışkan S, Akkasoglu S, Sargon MF, Demiryurek MD. Mastoid process morphometry on dry skulls. Kırıkkale Uni Med J. 2020;22(1):58-63.

15. Chaudhary RK, Mahajan A, Piplani M, Khurana BS. Determination of sex from mastoid dimensions among North Indians. Medico-legal Update. 2019;19(1):65-9.

16. Ursi WJ, Trotman CA, McNamara JA, Behrents RG. Sexual dimorphism in normal craniofacial growth. Angle Orthod. 1993;63(1):47-56.

17. Keaney TC, Alster TS. Botulinum Toxin in men:Review of relevant anatomy and clinical trial data. Dermatol Surg. 2013;39:1434-43.

18. Rosas A, Bastir M. Thin-Plate spline analysis of allometry and sexual dimorphism in the human craniofacial complex. Am J Phys Anthropol. 2002;117:236 -45. 
19. Holton NE, Alsamawi A, Yokley TR, Froehle AW. The ontogeny of nasal shape:An analysis of sexual dimorphism in a longitudinal sample. Am J Phys Anthropol. 2016;160(1):52-61.

20. Huxley AK. Analysis of shrinkage in human fetal diaphyseal lengths from fresh to dry bone using Petersohn and Kohler's data. J Forensic Sci. 1998,43:423-6.

21. Nagaoka T, Kawakubo Y. Using the petrous part of the temporal bone to estimate fetal age at death. Forensic Sci Int. 2015;248:188.e1-188.e7.

22. Simpson E, Henneberg M. Variation in soft-tissue thicknesses on the human face and their relation to craniometric dimensions. Am J Phys. Anthropol. 2002;118(2):121-33. 